Marquette University

e-Publications@Marquette

Theology Faculty Research and Publications

Theology, Department of

9-1-1977

\title{
Book Review: Death, Dying and the Biological Revolution: Our Last Quest for Responsibility
}

Daniel C. Maguire

Marquette University, daniel.maguire@marquette.edu

Published version. Theological Studies, Vol. 38, No. 3 (September 1977): 594-596. DOI. (C) 1977

Theological Studies, Inc. Used with permission. 
Death, Dying, and the Biological Revolution: Our Last Quest FOR ResPonsibility. By Robert M. Veatch. New Haven: Yale Univ. Press, 1976. Pp. 323. \$12.95.

V. has added a valuable volume to the burgeoning literature on the ethical and policy questions related to death and dying. It is V.'s belief that "the best hope for gaining insight into the complex dilemmas posed by the technological and biological revolutions is an eclectic spirit combining contributions from many disciplines." In this spirit he considers the moral meaning of death, the definition of death, the choice not to prolong dying, the right to refuse treatment, and the policy issues related to all of this. He also discusses the patient's right to have the truth, and the moral and policy issues regarding the newly dead. V. states that his book is not primarily "a philosophical analysis of the ethics of death and dying," and this is somewhat true in view of the broad interdisciplinary range of the work. Still, he does develop some significant ideas in a way that is enriching to ethical theory.

For example, V. appreciates that the death question is foundational, that it poses anew the question of the meaning of the good life, since to ask the meaning of death draws us into the question of the meaning of life. He accosts the still regnant illusions of value-free science and is effective in showing the philosophical and theological judgments and values implicit in supposedly detached empirical analyses. He is also 
good in elucidating the crucial ethical considerations involved in the doctor's decision regarding what the patient should be told. V. is not overawed by "the technological priesthood." In this and in other ways, V. illustrates two of the promising advantages of the current rush to bioethics: first, it can draw the ethicist to the foundations of ethical theory where his major contributions are due, and secondly, bioethics is constructing paradigms for the other hard and soft sciences which can aid them in investigating the value-laden content of their disciplines and in demonstrating their inherent need for inclusion in ethical discourse. Bioethics betrays its promise when it remains an issue-hopping exercise which eschews theoretical depth. There are other strengths in V.'s book: his analysis of the ordinary/extraordinary-means distinction is telling; he is strong on stressing the centrality of the patient's all-tooneglected interests; his proposed statute regarding the determination that a person has died advances that discussion; and his bibliographical richness regarding all issues treated is one of the decided values of the book.

I would take issue at some points. V. allows that there may be "rare cases where active killing of the dying might be morally justified." He also suggests that "we may want active killing of dying patients to remain illegal even in those rare cases where it might be morally justified." These positions, which are not self-evident, need more development than they are given. Indeed, the view that the instances of moral mercy death should be handled preterlegally seems to me a thesis that will not stand. V. concedes too much to the contention of the medical priesthood that "pain and suffering can virtually always be controlled." There are important differences between pain and suffering, and radical limits in the control of medicine over the latter. This distinction is often, as here, missed. $V$. finds it hard to see why there should be any moral distinction between stopping a treatment once started, and failing to start it in the first place. That distinction may, however, be defended on the critical grounds of the moral significance of consequences, both psychological and social. Valid distinctions are based on differences, and there are differences here. $V$. is also not on good ground when he speaks of the use of "probable opinion," probabiliorism, and tutiorism in deciding cases where "there is moral or philosophical doubt about whether someone is dead." These systems in Catholic moral thought were not developed to address questions of doubtful fact but only of doubtful liceity. Also, it is not correct to say that the "Roman Catholic Church stands firm" on the position that direct termination of innocent life is always morally wrong. The Roman Catholic Church is not theologically monolithic on this at this time; there are solidly probable alternatives to the older view. With all of this 
596 THEOLOGICAL STUDIES

said, however, V.'s book should be seen as a strong and significant contribution.

Marquette University DanIEL C. Maguire 